\title{
KECERDASAN DAN KINERJA KARYAWAN
}

\author{
Fitri Setya Ma'rufah, Siswanto \\ Fakultas Ekonomi UIN Maulana Malik Ibrahim Malang \\ Email: siswanto@pbs.uin-malang.ac.id
}

\begin{abstract}
Intelligencies have an important role to improve employee performance. There was a research gap related the role. This research is to analyze the effect of intelligence dimensions on employee performance. The sample of the study consisted of 67 respondents. Quantitative analysis is used. The results showed intellectual qoutient, emotional quotient, and spiritual quotient could improve employee performance. Meanwhile, spiritual intelligence had dominant role.
\end{abstract}

Keywords: intellectual quotient, emotional quotient, spiritual quotient, work performance

\section{Cara mencitasi:}

Ma'rufah, F.S \& Siswanto (2019). Kecerdasan Dan Kinerja Karyawan. Iqtishoduna: Jurnal Ekonomi Dan Bisnis Islam. Vol 15 (1): 39-56.

\section{Pendahuluan}

Sumberdaya manusia merupakan aset terpenting dalam organisasi. Ardana, Mujiati, Utama (2012) menyatakan sumberdaya manusia merupakan aset penting karena berperan sebagai penentu keberhasilan organisasi. Sumber daya manusia yang berkualitas akan menunjukkan hasil kerja yang optimal. Rivai (2006) menyatakan hasil kerja merupakan cerminan kinerja karyawan.

Kinerja karyawan merupakan hasil kerja, baik secara kualitas maupun kuantitas. Mangkunegara (2005) menyatakan kinerja karyawan merupakan hasil kerja secara kuantitas dan kualitas yang dicapai seseorang karyawan dalam melaksanakan tugas sesuai dengan tanggung jawab yang diberikan. Kinerja merupakan suatu fungsi dari motivasi dan kemampuan (Rivai, 2006). Kemampuan tersebut mencakup kemampuan potensi (kecerdasan) dan kemampuan reality (knowledge dan skill) (Mangkunegara, 2005).

Kinerja karyawan dipengaruhi oleh faktor internal dan faktor eksternal. Tika (2006) menyatakan kinerja karyawan dipengaruhi adanya faktor internal dan eksternal. Faktor eksternal meliputi peraturan ketenagakerjaan, keinginan pelanggan, nilai-nilai sosial, serikat buruh, kondisi ekonomi, perubahan lokasi kerja, dan kondisi pasar. Sedangkan, faktor internal meliputi 
Fitri Setya Ma'rufah, Siswanto

ketrampilan, kestabilan emosi, motivasi, persepsi perasaan, kondisi keluarga, kondisi fisik dan karakteristik kelompok, serta variabel kecerdasan. Kecerdasan merupakan faktor penting untuk meningkatkan kinerja karyawan. Wijaya (2014) dan Waryanti (2011) menunjukkan bahwa kecerdasan mempengaruhi kinerja karyawan.

Kecerdasan diproksikan dalam tiga jenis. Zohar and Marshall (2005) menyatakan kecerdasan dapat diklasifikasi menjadi kecerdasan intelektual (Intellectual quotient atau IQ), kecerdasana emosional (emotional quotient atau EQ), dan kecerdasan spiritual (spiritual quotient atau SQ). Kecerdasan intelektual merupakan jenis kecerdasan yang digunakan untuk memecahkan masalah logika dan strategis. Adapun, kecerdasan emosional mencerminkan kecerdasan yang memberi rasa empati, cinta, motivasi, dan kemampuan untuk menanggapi kesedihan atau kegembiraan secara tepat (Efendi, 2005). Sedangkan, kecerdasan spiritual merupakan kecerdasan yang memungkinkan manusia menjadi kreatif, mengubah aturan dan situasi (Efendi, 2005).

Kecerdasan intelektual seringkali lebih dihargai dibandingkan kecerdasan yang lain. Walaupun, Pasiak (2002) menunjukkan bahwa kecerdasan emosional merupakan indikator kunci kesuksesan. Goleman juga menyatakan pencapaian kinerja ditentukan hanya 20\% dari kecerdasan intelektual (IQ), sedangkan 80\% lagi ditentukan oleh emotional quotient (EQ) (Mangkunegara, 2005:93). Kecerdasan emosional ini dapat dikembangkan. Zohar and Marshall (2005) menyatakan kecerdasan emosional dapat dikembangkan dan dipelihara. Lebih lanjut, mereka menyatakan skor kecerdasana intelektual jarang mengalami perubahan besar sepanjang hidup orang.

Penelitian tentang kecerdasan terhadap kinerja karyawan telah dilakukan sebelumnya. Penelitian-penelitian itu menunjukkan hasil yang berbeda-beda. Moniaga (2013) menunjukkan kecerdasan intelektual, kecerdasan emosional, dan kecerdasan spiritual berpengaruh signifikan terhadap kinerja karyawan. Kecerdasan intelektual berpengaruh paling dominan terhadap kinerja karyawan. Rahmasari (2012) menunjukkan kecerdasan intelektual, kecerdasan emosi dan kecerdasan spiritual meningkatkan kinerja karyawan. Sedangkan, kecerdasan emosi berpengaruh paling dominan terhadap kinerja karyawan. Walaupun kecerdasan intellectual, kecerdasan emosional, dan kecerdasan spiritual dapat meningkatkan kinerja karyawan, namun variabel dominan yang mempengaruhi kinerja karyawan menunjukkan hasil yang berbeda. Wijaya (2014) dan Waryanti (2011) menunjukkan kecerdasan spiritual berpengaruh paling dominan terhadap kinerja karyawan. 
Penelitian tentang kecerdasan terhadap kinerja karyawan masih menunjukkan hasil yang berbeda-beda. Al Fharied (2014) menunjukkan hanya kecerdasan emosional yang berpengaruh terhadap kinerja karyawan. Sedangkan, kecerdasan intelektual dan kecerdasan spiritual tidak berpengaruh terhadap kinerja karyawan. Adapun, Simanjorang dan Sipayung (2012) menunjukkan kecerdasan emosional dan kecerdasan spiritual berpengaruh signifikan positif terhadap sikap etis mahasiswa, sementara kecerdasan intelektual tidak berpengaruh signifikan terhadap sikap etis mahasiswa. Sedangkan penelitian Artana dkk (2014) menyatakan bahwa kecerdasan intelektual, kecerdasan emosional, dan perilaku belajar berpengaruh positif dan signifikan terhadap pemahaman akuntansi, sementara kecerdasan spiritual berpengaruh negatif terhadap pemahaman akuntansi.

Perbedaan hasil-hasil penelitian tersebut masih menjadi perdebatan di kalangan praktisi dan akademisi guna melihat variabel yang lebih berperan. Ketidakkonsistenan hasil penelitian menimbulkan kontradiksi. Oleh karena itu, perlu melakukan penelitian tentang peran kecerdasan intelektual, kecerdasan emosional, dan kecerdasan spiritual terhadap kinerja karyawan.

Penelitian ini dilakukan di unit pelaksana teknis daerah yang menangani kesehatan, yakni di pusat kesehatan masyarakat atau puskesmas. Puskesmas menjadi pusat pelayanan kesehatan publik. Puskemas berperan menyelenggarakan pelayanan kesehatan masyarakat agar derajat kesehatan masyarakat meningkat. Peran tanaga medis dan paramedis menjadi bagian penting dalam meningkatkan kepuasan masyarakat. Kepuasan konsumen yang ditunjukkan dengan adanya kepuasan masyarakat atau pasien merupakan kinerja yang diproyeksikan tercapai. Karena, kinerja karyawan dapat menghasilakn kepuasan pasien. Berdasarkan survei awal 7 dari 10 orang konsumen pada obyek penelitian menyatakan bahwa, belum puas dengan kinerja yang diberikan karyawan. Hal ini menunjukkan kinerja karyawan puskesmas belum maksimal. Hal ini disebabkan karena ada faktorfaktor yang mempengaruhinya.

Kinerja dalam lingkup pelayanan kesehatan berkaitan erat dengan kecerdasan intelektual, kecerdasan emosional, dan kecerdasan spiritual. Karena, pemberian pelayanan karyawan berhubungan langsung dengan konsumen sehingga ketiga kecerdasan tersebut harus selalu diselaraskan. Untuk menghadapi persaingan dan menjaga loyalitas konsumen. Karyawan Puskesmas diharapkan memiliki bekal kecerdasn intelektual, karena penanganan kesehatan memiliki risiko tinggi terhadap kesehatan sehingga harus ditangani oleh tenaga ahli dalam bidangnya. Kecerdasan emosional 
Fitri Setya Ma'rufah, Siswanto

tentunya juga harus dimiliki oleh karyawan karena harus memberikan pelayanan kepada individu yang beragam, sehingga memiliki kecerdasan intelektual saja tidak cukup, oleh karena itu dibutuhkan kecerdasan emosional. Guna menyempurnakan fungsi kecerdasan intelektual dan kecedasan emosional maka dilengapi dengan kecerdasan spiritual. Tingkat kecerdasan merupakan salah satu faktor kinerja karyawan, sehingga kecerdasan mempengaruhi kinerja karyawan. Tujuan penelitian untuk menganalisis pengaruh kecerdasan yang meliputi kecerdasan intelektual, kecerdasan emosional, dan kecerdasan spiritual terhadap kinerja karyawan. Analisis regresi digunakan untuk mengetahui pengaruh kecerdasan intelektual, kecerdasan emosional, dan kecerdasan spiritual terhadap kinerja karyawan.

\section{Kajian Pustaka}

\section{Kinerja}

Kinerja merupkan hasil kerja, baik secara kualitas maupun kuantitas. Mangkunegara (2005) menyatakan kinerja merupakan hasil kerja secara kualitas dan kuantitas yang dicapai seseorang ketika melaksanakan tugas dan tanggung jawabnya. Faktor yang menentukan kinerja karyawan terdiri atas faktor internal dan faktor eksternal.

Faktor internal ini meliputi kecerdasan, ketrampilan, kestabilan emosi, motivasi, persepsi peran, kondisi keluarga, kondisi fisik, dan sebagainya. Sedangkan, faktor eksternal terdiri atas peraturan ketenagakerjaan, keinginan pelanggan, nilai-nilai sosial, serikuat buruh, dan sebagainya (Tika, 2006). Kinerja mempengaruhi seberapa banyak mereka memberikan kontribusi kepada organisasi yang meliputi kualitas, kuantitas, jangka waktu, kehadiran di tempat kerja dan sikap kooperatif (Mathis \& Jackson, 2002).

\section{Kecerdasan Intelektual}

Kecerdasan intelektual merupakan kemampuan yang diperlukan untuk melakukan berbagai aktivitas mental pikiran, menalar dan memecahkan masalah (Robbins dan Judge, 2008). Kemampuan untuk belajar dari pengalaman, berfikir menggunakan proses-proses metakognitif, dan kemampuan untuk beradaptasi dengan lingkungan sekitar merupakan kecerdasan intelektual. Indikator kecerdasan intelektual meliputi kemampuan pemecahan masalah, intelegensi verbal, dan intelegensi praktis (Azwar, 2006).

\section{Kecerdasan Emosional}

Kecerdasan emosional merupakan kecerdasan yang berkaitan dengan kemampuan mengenali perasaaan diri dan perasaan orang lain. Goleman (1999) menyatakan kecerdasan emosional meliputi kemampuan mengenali 
diri dan orang lain, kemampuan inovasi, kemampuan mengelola emosi terkait dengan diri sendiri maupun berhubungan dengan orang lain. Salah satu cara meningkatkan keunggulan kompetitif sumberdaya manusia adalah melalui peningkatan kecerdasan emosional (Mangkunegara, 2005). Unsur utama kecerdasan emosional terdiri atas kecerdasan diri, pengaturan diri, motivasi, empati, dan ketrampilan sosial (Goleman, 1999).

\section{Kecerdasan Spiritual}

Kecerdasan spiritual merupakan kecerdasan dalam menghadapi persoalan makna dan nilai (Zohar dan Marshal, 2005). Sutrisno (2010) menjelaskan kecerdasan spiritualitas berkaitan dengan kecerdasan untuk menghadapi dan memecahkan persoalan makna dan nilai. Kecerdasan ini menempatkan perilaku dan hidup seseorang dalam konteks makna menjadikan manusia menjalani hidupnya dengan penuh makna. Wahab dan Umiarso (2011) menyatakan kecerdasan spiritual ada dalam diri manusia sejak lahir. Dengan kecerdasan ini menjadikan manusia menjalani hidup penuh makna, mendengar suara hati nurani, tidak merasa sia-sia, dan semua yang dijalani selalu bernilai.

\section{Hubungan Antar Variabel}

\section{Kecerdasan Intelektual dan Kinerja Karyawan.}

Kecerdasan intelektual atau IQ diproyeksikan menentukan kemampuan individu. Sesorang yang memiliki IQ tinggi, maka dianggap semakin tinggi kecerdasannya (Zohar and Marshall, 2002). Karyawan dengan kecerdasan intelektual tinggi diharapkan menghasilkan kinerja yang lebih baik. Karyawan yang memiliki kecerdasan intelektual tinggi lebih mudah memahami pengetahuan. Oleh karena itu, mereka memiliki kemampuan memecahkan masalah yang lebih baik. Kecerdasan intelektual dibutuhkan karyawan untuk meningkatkan kinerja atau keberhasilan dalam pekerjaannya. (Trihandini, 2005:18-20). Kecerdasan intelektual yang tinggi akan meningkatkan kinerja karyawan (Moniaga, 2013). Artana, dkk (2014) juga menunjukkan kecerdasan intelektual berpengaruh positif signifikan terhadap kinerja karyawan. Berdasarkan hasil kajian pustaka tersebut, maka hipotesis penelitian menyatakan:

\section{Hipotesis 1: Kecerdasan intelektual berpengaruh positif signifikan terhadap kinerja karyawan.}

\section{Kecerdasan Emosional dan Kinerja}

Kecerdasan emosional berperan penting dalam mencapai kesuksesan di ddunia kerja, disamping kecerdasan intelektual yang dibutuhkan (Goleman, 
Fitri Setya Ma'rufah, Siswanto

2000). Karyawan yang memiliki kecerdasan emosional yang tinggi akan meningkatkan kinerja dan hasil kerja yang lebih baik pula (Agustian, 2001). Kinerja karyawan tidak akan berkembang jika tidak memiliki kecerdasan emosional yang memadai (Dwijayanti, 2009).

Kecerdasan emosional dapat meningkatkan kinerja karyawan. $\mathrm{Al}$ Fharied, 2014 menunjukkan kecerdasan emosional berpengaruh terhadap kinerja karyawan. Rahmasari (2012) juga menunjukkan kecerdasaan emosional meningkatkan kinerja karyawan. Berdasarkan argumentasi diatas, maka hipotesis penelitian:

\section{Hipotesis 2: Kecerdasan emosional berpengaruh positif signifikan terhadap kinerja karyawan.}

\section{Kecerdasan Spiritual dan Kinerja Karyawan}

Kecerdasan spiritual atau Sq merupakan kecerdasan yang berkaitan dengan kemampuan seseorang untuk mengekspresikan dan memberi makna pada setiap tindakannya. Oleh karena itu, untuk meningkatkan kinerja, maka diperlukan kecerdasan spiritual (Munir, 2000). Jenjang karir karyawan dapat ditentukan dari kecerdasan spiritual. Kecerdasan spiritual dapat meningkatkan kinerja karwayan, karena kecerdasan ini menimbulkan rasa tenang dan dorongan (motivasi) bekerja lebih baik (Wiersma, 2002).

Kecerdasan spiritual mampu meningkatkan kinerja karyawan. Wijaya (2014) menunjukkan kecerdasan spiritual berpengaruh positif dan signifikan terhadap peningkatan kinerja karyawan. Waryanti (2011) juga menunjukkan peran penting kecerdasan spiritual terhadap peningkatan kinerja karyawan. Berdasarkan hasil kajian pustaka tersebut, maka hipotesis penelitian:

\section{Hipotesis 3: Kecerdasan spiritual berpengaruh positif kinerja karyawan.}

\section{Metode}

Penelitian ini menggunakan pendekatan kuantitatif. Secara paradigma, penelitian ini menggunakan paradigma positivistik. Siswanto (2012) menyatakan paradigma positivistik merujuk pada filosofi deterministik, terdapat variabel yang menjadi sebab atas hasil darinya. Kecerdasam sebagai sebab yang dapat meningkatkan kinerja karyawan. Sampel penelitian terdiri atas 67 responden. Terdiri atas $86,6 \%$ tenaga medis dan 13,4\% sebagai tenaga non medis. Analisis data menggunakan analisis regresi berganda dan analisis komparatif. Variabel penelitian terdiri atas kecerdasan intelektual, kecerdasan emosional, dan kecerdasan spiritual, serta variabel kinerja karyawan. Tiga 
variabel kecerdasan tersebut sebagai variabel bebas, sedangkan kinerja karyawan sebagai variabel terikat.

Variabel kinerja karyawan dipahami sebagai pencapaian hasil kerja, baik secara kualitas maupun kuantitas. Adapun, indikator kinerja karyawan ini meliputi kualitas, kuantitas, jangka waktu, kehadiran di tempat kerja dan sikap kooperatif (Mathis \& Jackson, 2002).

Kecerdasan intelektual merupakan kemampuan yang berkaiatan dengan aktivitas mental pikiran, menalar dan memecahkan masalah (Robbins \& Judge, 2008). Indikator kecerdasan intelektual ini meliputi kemampuan pemecahan masalah, intelegensi verbal, dan intelegensi praktis (Azwar, 2006).

Kecerdasan emosional dipahami sebagai kemampuan mengenali perasaaan diri dan orang lain, kemampuan inovasi diri sendiri, serta kemampuan mengelola emosi. Indikator kecerdasan emosional ini meliputi kecerdasan diri, pengaturan diri, motivasi, empati, dan ketrampilan sosial (Goleman, 1999).

Kecerdasan spiritual merupakan kemampuan menghadapi dan memecahkan persoalan serta kemampuan untuk memaknai pekerjaan. Indikator kecerdasan spiritual meliputi fleksibelitas, kesadarab diri, kemampuan menghadapi dan memanfaatkan penderitaan, kemampuan menghadapi dan melampaui rasa sakit, kualitas hidup yang diilhami visi dan nilai-nilai, keengganan untuk menyebabkan kerugian, kecenderungan melihat keterkaitan antara berbagai hal, kecenderungan bertanya mengapa dan bagaimana, dan mandiri (Zohar \& Marshall, 2002:14).

\section{Analisis Data}

Penelitian ini menggunakan analisis regresi berganda, uji beda, dan crosstabs dengan aplikasi IBM Statistic SPSS 20. Analisis regresi berganda digunakan untuk menganalisis pengaruh variabel IQ, EQ, dan SQ terhadap kinerja karyawan, serta untuk mengetahui variabel yang berpengaruh dominan. Uji beda dilakukan untuk menganalisis perbedaan pada level spiritual quotient (SQ) sebagai variabel dominan dengan pendidikan terakhir karyawan. Pada penelitian ini uji beda dilakukan dengan metode one-way ANOVA digunakan untuk menguji hubungan antar satu variabel dependen dengan satu atau lebih independen (Ghozali, 2011). Crosstab digunakan untuk menampilkan kaitan antara dua atau lebih variabel (Nisfiannoor, 2009).

\section{Pembahasan}

Jumlah responden penelitian ini sebanyak 67 orang sebagai karyawan Pusat Kesehatan Masyarakat (puskemas) di Kabupaten Madiun. Berdasarkan usia, responden berusia 16-25 tahun sebanyak 1 orang (2\%). Usia 26-35 tahun 
Fitri Setya Ma'rufah, Siswanto

sebanyak 16 orang (24\%). Responden yang memiliki usia 36-45 tahun sebanyak 29 orang (43\%). Sedangkan, responden berusia 46-55 tahun sebanyak 15 orang (22\%), dan usia $\geq 56$ tahun sebanyak 6 orang (6\%). Berdasarkan jenis kelamin, responden laki-laki lebih sedikit dibanding perempuan yakni sebanyak 18 orang (27\%). Sedangkan, responden perempuan sebanyak 49 orang (73\%).

Berdasarkan pendidikan terakhir, karyawan yang berpendidikan SD sebanyak 6 orang (9\%). Responden berpendidikan SMP sebanyak 1 orang (2\%). Responden berpendidikan SMA sebanyak 9 orang (13\%). Sedangkan, pendidikan diploma sebanyak 41 orang (61\%). Responden berpendidikan sarjana strata satu (S1) sebanyak 8 orang (11\%), dan responden berpendidikan sarjana strata dua (S2) sebanyak 2 orang (3\%).

Berdasarkan status kepegawaian, karyawan diklasifikasikan menjadi karyawan tetap, karyawan tidak tetap, dan karyawan kontrak. Jumlah responden sebagian besar berstatus pegawai tetap, yakni sebanyak 56 orang (84\%). Sedangkan, jumlah pegawai tidak tetap sebanyak 5 orang (7\%). Adapun jumlah responden berstatus pegawai kontrak sebanyak 6 orang (9\%).

Berdasarkan status kepegawaian, karyawan diklasifikasikan menjadi karyawan tetap, karyawan tidak tetap, dan karyawan kontrak. Jumlah responden sebagian besar berstatus pegawai tetap, yakni sebanyak 56 orang (84\%). Sedangkan, jumlah pegawai tidak tetap sebanyak 5 orang (7\%). Adapun jumlah responden berstatus pegawai kontrak sebanyak 6 orang (9\%).

Karakteristik responden juga dikelompokkan berdasarkan tingkat penghasilan. Berdasarkan tingkat penghasilan per bulan, sebanyak 10 orang (15\%). Adapun, karyawan berpenghasilan per bulan sebesar kurang dari 1 juta sebanyak 43 orang (64\%). karyawan berpenghasilan per bulan sebesar 2,1 juta sampai 3 juta, sebanyak 11 orang (16\%) karyawan berpenghasilan per bulan sebesar Rp. 3,1 juta sampai 4 juta dan sebanyak 3 orang (5\%) karyawan berpenghasilan per bulan lebih dari 4 juta rupiah.

Berdasarkan jenis pekerjaannya responden dikelompokkan menjadi tenaga medis dan tenaga non medis. Sebanyak 58 orang (87\%) karyawan sebagai tenaga medis. Sedangkan, 9 responden $(13 \%)$ tenaga non medis. Berdasarkan masa kerja, sebanyak 14 orang (21\%) karyawan memiliki masa kerja selama 1-5 tahun, sebanyak 32 orang (48\%) memiliki masa kerja 6-10 tahun, sebanyak 1 orang (2\%) memiliki masa kerja 11-15 tahun 
Tabel 1. Karakteristik Responden

\begin{tabular}{|c|c|c|c|}
\hline Karakteristik & Kategori & Jumlah & $\%$ \\
\hline \multirow[t]{2}{*}{ Jenis Kelamin } & Laki-Laki & 18 & 27 \\
\hline & Perempuan & 49 & 73 \\
\hline \multirow[t]{5}{*}{ Kelompok Usia } & $16-25$ & 1 & 2 \\
\hline & $26-35$ & 16 & 24 \\
\hline & $36-45$ & 29 & 44 \\
\hline & $46-55$ & 15 & 13 \\
\hline & $\geq 56$ & 6 & 9 \\
\hline \multirow[t]{3}{*}{ Status Ketenagakerjaan } & Tetap & 56 & 84 \\
\hline & Tidak tetap & 5 & 7 \\
\hline & Kontrak & 6 & 9 \\
\hline \multirow[t]{6}{*}{ Tingkat pendidikan } & SD/sederajat & 6 & 9 \\
\hline & SMP/sederatat & 1 & 2 \\
\hline & SMA/sederajat & 9 & 13 \\
\hline & Diploma & 41 & 61 \\
\hline & $\mathrm{S} 1$ & 8 & 12 \\
\hline & S2 & 2 & 3 \\
\hline \multirow[t]{5}{*}{ Masa Kerja } & 1-5 tahun & 14 & 20 \\
\hline & 6-10 tahun & 32 & 48 \\
\hline & 11-15 tahun & 1 & 2 \\
\hline & 16-20 tahun & 1 & 2 \\
\hline & $\geq 21$ tahun & 9 & 28 \\
\hline \multirow[t]{2}{*}{ Jenis Pekerjaan } & Tenaga medis & 58 & 87 \\
\hline & Tenaga non medis & 9 & 13 \\
\hline \multirow[t]{5}{*}{ Tingkat Pendapatan } & $\leq 1$ Juta & 10 & 15 \\
\hline & 1 Juta - 2 Juta & 0 & 0 \\
\hline & 2,1 Juta - 3 Juta & 43 & 64 \\
\hline & 3,1 juta - 4 Juta & 11 & 16 \\
\hline & $\geq 4$ Juta & 3 & 5 \\
\hline
\end{tabular}

Sumber: data diolah

Sebanyak 1 orang (2\%) memiliki masa kerja 16-20 tahun, dan sebanyak 13 orang $(28 \%)$ memiliki masa kerja $\geq 21$ tahun.

Hasil analisis menunjukkan tingkat kinerja memiliki nilai skor yang tinggi. Hal tersebut dapat dilihat dari nilai rata-rata kinerja karyawan dalam penelitian ini. Kecerdasaran spiritual karyawan memiliki skor yang paling tinggi setelah variabel kinerja karyawan. Variabel kecerdasan memiliki korelasi yang bermakna terhadap variabel kinerja karyawan. Hal ini ditunjukkan korelasi variabel dimensi kecerdasan yang meliputi kecerdasan intelektual, kecerdasan emosional, dan kecerdasan spiritual dengan variabel kinerja karyawan memiliki tingkat siginifikansi kurang dari 1\%. 
Fitri Setya Ma'rufah, Siswanto

Uji reliabilitas diketahui melalui koefisien cronbach alpha. Hasil analisis reliabilitas menunjukkan nilai cronbach alpha masing-masing variabel lebih besar dari 0,8. Hal ini menunjukkan bahwa semua variabel dalam penelitian sangat reliabel. Hasil nilai rata-rata implementasi variabel dalam penelitian, nilai skor, korelasi dapat dilihat dalam Tabel 2

Tabel 2. Rata-rata, Nilai Skor, Korelasi, dan Reliabilitas

\begin{tabular}{lcccccc}
\hline Variabel & $\begin{array}{c}\text { Rata- } \\
\text { rata }\end{array}$ & $\begin{array}{c}\text { Nilai } \\
\text { Skor }\end{array}$ & $\mathbf{1}$ & $\mathbf{2}$ & $\mathbf{3}$ & $\mathbf{4}$ \\
\hline $\begin{array}{l}\text { 1. Kinerja } \\
\text { Karyawan }\end{array}$ & 3,82 & Tinggi & $(0,895)$ & & & \\
\hline $\begin{array}{l}\text { 2. Kecerdasan } \\
\text { intelektual }\end{array}$ & 3,71 & Tinggi & $0,514^{* *}$ & $(0,844)$ & & \\
\hline $\begin{array}{l}\text { 3. Kecerdasan } \\
\text { emosional }\end{array}$ & 3,66 & Tinggi & $0,581^{* *}$ & $0,432^{* *}$ & $(0,869)$ & \\
\hline $\begin{array}{l}\text { 4. Kecerdasan } \\
\text { spiritual }\end{array}$ & 3,77 & Tinggi & $0,693^{* *}$ & $0,310^{*}$ & $0,469^{* *}$ & $(0,882)$ \\
\end{tabular}

Nilai Cronbach alpha ditunjukkan dalam tanda kurung

$* \mathrm{p}<0,05 ; * * \mathrm{p}<0,01$

Kinerja karyawan berdasarkan karakteristik responden dapat dijelaskan lebih lanjut. Karakteristik biografis responden dapat menentukan perbedaan kinerja karyawannya. Kinerja karyawan pegawai laki-laki lebih tinggi dibandingkan dengan kinerja perempuan. Namun, berdasarkan hasil analisis komparatif menunjukkan tidak ada perbedaan yang bermakna (signifikan) kinerja pegawai berdasarkan jenis kelamin. Nilai t hitung kinerja karyawan berdasarkan jenis kelamin sebesar 0,005 dengan tingkat probabilitas 0,996. Nilai probabilitas $\mathrm{t}$ hitung tersebut lebih besar dari 5\% sehingga dapat disimpulkan tidak ada perbedaan kinerja karyawan berdasarkan jenis kelamin. Hal ini dapat dilihat dalam tabel 3.

Kinerja karyawan berdasarkan kelompok usia menunjukkan bahwa karyawan dengan kelompok usia diatas 55 tahun memiliki kinerja yang paling ini. Hal ini dapat menjelaskan adanya peran pengalaman yang berkontribusi pada peningkatan kinerja. Sedangkan, karyawan yang usianya kurang dari 26 tahun memiliki kinerja yang paling kecil. Namun demikian, hasil analisis komparatif kinerja karyawan berdasarkan kelompok usia menunjukkan tidak 
ada perbedaan kinerjanya secara bermakna. Hal ini diketahui dengan nilai $\mathrm{F}$ hitung sebesr 1,658 dengan tingkat probabalitas kinerja karyawan berdasarkan kelompok usia lebih besar dari 0,05, yakni sebesar 0,171.

Karyawan kontrak pada penelitian ini ternyata memiliki kinerja paling tinggi dibandingkan dengan karyawan tetap dan karyawan tidak tetap. Harapan memperoleh pengakuan dan kejelasan status menjadi pemicu menunjukkan kinerja terbaik. Walaupun demikian, kinerja karyawan berdasarkan status kepegawaian ini menunjukkan tidak ada perbedaan yang signifikan. Hal ini dapat diketahui dari nilai $\mathrm{F}$ hitung kinerja karyawan berdasarkan karakteristik status kepegawaian sebesar 2,441 dengan tingkat probabilitas 0,098. Nilai probabilitas ini lebih besar dari 0,05 sehingga disimpulkan tidak ada perbedaan kinerja berdasarkan status kepegawaian.

Kinerja karyawan berdasarkan tingkat pendidikan menunjukkan bahwa tingkat pendidikan sarjana strata satu dan sarjana strata dua memiliki kinerja yang tinggi. Sedangkan, kinerja karyawan yang rendah dicerminkan pegawai dengan tingkat pendidikan SMA. Walaupun demikian, kinerja karyawan berdasarkan tingkat pendidikan menunjukkan perbedaan yang tidak bermakna.

Hasil analisis komparatif menunjukkan nilai $\mathrm{F}$ hitung sebesar 1,902 dengan probabilitas sebesar 0,107. Nilai probabiltas tersebut lebih besar dari 0,05 sehingga menunjukkan tidak terdapat perbedaan kinerja karyawan berdasarkan tingkat pendidikan.

Karyawan kontrak pada penelitian ini ternyata memiliki kinerja paling tinggi dibandingkan dengan karyawan tetap dan karyawan tidak tetap. Harapan memperoleh pengakuan dan kejelasan status menjadi pemicu menunjukkan kinerja terbaik. Walaupun demikian, kinerja karyawan berdasarkan status kepegawaian ini menunjukkan tidak ada perbedaan yang signifikan. Hal ini dapat diketahui dari nilai $\mathrm{F}$ hitung kinerja karyawan berdasarkan karakteristik status kepegawaian sebesar 2,441 dengan tingkat probabilitas 0,098. Nilai probabilitas ini lebih besar dari 0,05 sehingga disimpulkan tidak ada perbedaan kinerja berdasarkan status kepegawaian.

Kinerja karyawan berdasarkan tingkat pendidikan menunjukkan bahwa tingkat pendidikan sarjana strata satu dan sarjana strata dua memiliki kinerja yang tinggi. Sedangkan, kinerja karyawan yang rendah dicerminkan pegawai dengan tingkat pendidikan SMA. Walaupun demikian, kinerja karyawan berdasarkan tingkat pendidikan menunjukkan perbedaan yang tidak bermakna.

Hasil analisis komparatif menunjukkan nilai $\mathrm{F}$ hitung sebesar 1,902 dengan probabilitas sebesar 0,107. Nilai probabiltas tersebut lebih besar dari 
Fitri Setya Ma'rufah, Siswanto

0,05 sehingga menunjukkan tidak terdapat perbedaan kinerja karyawan berdasarkan tingkat pendidikan.

Tabel 3. Analisis Komparatif Kinerja Karyawan Berdasarkan

Karakteristik Responden

\begin{tabular}{|c|c|c|c|c|c|}
\hline Karakteristik & Kategori & $\begin{array}{l}\text { Rata- } \\
\text { rata }\end{array}$ & SD & $\begin{array}{c}\text { Nilai } \\
\text { T }\end{array}$ & $\begin{array}{c}\text { Probabilita } \\
\text { s }\end{array}$ \\
\hline \multirow[t]{2}{*}{ Jenis Kelamin } & Laki-Laki & 3,821 & 0,549 & \multirow[t]{2}{*}{0,005} & \multirow[t]{2}{*}{0,996} \\
\hline & Perempuan & 3,820 & 0,407 & & \\
\hline \multirow[t]{5}{*}{ Kelompok Usia } & $16-25$ & 3,430 & - & \multirow[t]{5}{*}{1,658} & \multirow[t]{5}{*}{0,171} \\
\hline & $26-35$ & 3,834 & 0,523 & & \\
\hline & $36-45$ & 3,822 & 0,323 & & \\
\hline & $46-55$ & 3,681 & 0,518 & & \\
\hline & $\geq 55$ & 4,190 & 0,453 & & \\
\hline \multirow{4}{*}{$\begin{array}{l}\text { Status } \\
\text { Ketenagakerjaan }\end{array}$} & Tetap & 3770 & 0428 & \multirow{4}{*}{$\begin{array}{c}2,41 \\
1\end{array}$} & \multirow[t]{4}{*}{0,098} \\
\hline & & & & & \\
\hline & Tidak tetap & 3,842 & 0,327 & & \\
\hline & Kontrak & 4,190 & 0,483 & & \\
\hline \multirow[t]{6}{*}{ Tingkat pendidikan } & SD/sederajat & 3,998 & 0,382 & \multirow[t]{6}{*}{1,902} & \multirow[t]{6}{*}{0,107} \\
\hline & SMP/sederatat & 3,930 & - & & \\
\hline & SMA/sederajat & 3,525 & $\begin{array}{c}0,503 \\
0\end{array}$ & & \\
\hline & Diploma & 3,790 & $\begin{array}{c}0,411 \\
1\end{array}$ & & \\
\hline & S1 & 4,098 & 0,508 & & \\
\hline & $\mathrm{S} 2$ & 4,070 & 0,000 & & \\
\hline \multirow[t]{5}{*}{ Masa Kerja } & 1-5 tahun & 3,795 & 0,639 & \multirow[t]{5}{*}{$\begin{array}{c}0,15 \\
6\end{array}$} & \multirow[t]{5}{*}{0,960} \\
\hline & 6-10 tahun & 3,845 & 0,284 & & \\
\hline & 11-15 tahun & 4,000 & - & & \\
\hline & 16-20 tahun & 3,570 & - & & \\
\hline & $\geq 20$ tahun & 3,801 & 0,534 & & \\
\hline \multirow[t]{2}{*}{ Jenis Pekerjaan } & Tenaga medis & 3,828 & 0,413 & \multirow[t]{2}{*}{0,264} & \multirow[t]{2}{*}{0,798} \\
\hline & $\begin{array}{l}\text { Tenaga non } \\
\text { medis }\end{array}$ & 3,770 & 0,643 & & \\
\hline \multirow[t]{5}{*}{$\begin{array}{l}\text { Tingkat } \\
\text { Pendapatan }\end{array}$} & $\leq 1$ Juta & 3,949 & 0,361 & \multirow[t]{5}{*}{1,626} & \multirow[t]{5}{*}{0,192} \\
\hline & 1 Juta - 2 Juta & - & - & & \\
\hline & 2,1 Juta - 3 Juta & 3,774 & 0,483 & & \\
\hline & 3,1 juta -4 Juta & 3,760 & 0,300 & & \\
\hline & $\geq 4$ Juta & 4,283 & 0,369 & & \\
\hline
\end{tabular}

Sumber: data diolah 
Karyawan yang bekerja dalam kurun waktu 11-15 tahun memiliki kinerja yang tinggi. Sedangkan karyawan yang memiliki pengalaman kerja antara 1-5 tahun memiliki kinerja yang paling rendah. Walalupun demikian, kinerja karyawan berdasarkan masa kerja tidak berbeda secara signifikan. Hasil analisis komparatif menunjukkan nilai $\mathrm{F}$ hitung kinerja karyawan berdasarkan masa kerja sebesar 0,156 dengan probablitas sebesar 0,960. Berdasarkan analisis tersebut, maka nilai probabilitas lebih besar dari 0,05 sehingga disimpulkan tidak terdapat perbedaan kinerja karyawan berdasarkan masa kerja.

Kinerja karyawan medis lebih tinggi dibandingkan dengan tenaga non medis. Walaupun demikian, tidak terdapat perbedaan kinerja karyawan berdasarkan jenis pekerjaannya. Hal ini ditunjukkan dengan nilai t hitung sebesar 0,264 dan probabilitasnya sebesar 0,798. Nilai probabilitas t hitung lebih besar dari 0,05 sehingga disimpulkan tidak terdapat perbedaan kinerja karyawan berdasarkan jenis pekerjaannya.

Tingkat pendapatan tertinggi memiliki kinerja karyawan yang tinggi pula. Hal ini ditunjukkan dalam tabel 3 yang menunjukkan bahwa karyawan yang memiliki tingkat pendapatan lebih dari 4 juta memiliki kinerja tertinggi. Meskipun demikian, kinerja karyawan tidak berbeda nyata berdasrkan tingkat pendidikan. Hasil analisis komparatif menunjukkan nilai uji beda sebesar 1,626 dengan probabilitasnya 0,192. Level probabilitas ini lebih besar dari 5\% sehingga dapat disimpulkan bahwa tidak terdapat perbedaan kinerja karyawan berdasarkan tingkat penghasilan.

Tabel 4. Pengaruh Kecerdasan Intelektual, Kecerdasan Emosional, dan Kecerdasan Spiritual Terhadapa Kinerja Karyawan

\begin{tabular}{lcccccc}
\hline $\begin{array}{l}\text { Independen } \\
\text { Variabel }\end{array}$ & $\boldsymbol{\beta}$ & $\mathbf{t}$-hitung & Probabilitas t & $\mathbf{R}^{\mathbf{2}}$ & $\mathbf{F}$-hitung & Probabilitas F \\
\hline $\begin{array}{l}\text { Kecerdasan } \\
\text { intelektual }\end{array}$ & 0,365 & 2,964 & 0,004 & 0,619 & 34,054 & 0,000 \\
$\begin{array}{l}\text { Kecerdasan } \\
\text { emosional }\end{array}$ & 0,196 & 2,480 & 0,016 & & & \\
$\begin{array}{l}\text { Kecerdasan } \\
\text { spiritual }\end{array}$ & 0,424 & 5,677 & 0,000 & & & \\
\hline
\end{tabular}

Sumber: data diolah

Hasil analisis regresi berganda menunjukkan dimensi kecerdasan yang meliputi kecerdasan intelektual, kecerdasan emosional dan kecerdasan spiritual berpengaruh terhadap kinerja karyawan baik secara parsial maupun secara parsial. Tabel 4 menunjukkan bahwa probabilitas t hitung untuk uji 
Fitri Setya Ma'rufah, Siswanto

secara parsial dan probabilitas $\mathrm{F}$ hitung untuk uji simultan menunjukkan nilai dibawah 0,05. Oleh karena itu, dimensi kecerdasan tersebut berpengaruh terhadap kinerja karyawan.

Kecerdasan intelektual mempunyai pengaruh signifikan terhadap kinerja karyawan secara parsial. Hal ini ditunjukkan nilai probabilitas thitung sebesar 0,004. Tingkat probabilitas itu kurang dari 5\% sehingga disimpulkan terdapat pengaruh kecerdasan intelektual terhdapat kinerja karyawan. Koefesian beta menunjukkan pengaruh positif kecerdasan intelektual terhadap kinerja karyawan. Hasil ini menunjukkan bahwa kecerdasan intelektual akan meningkatkan kinerja karyawan.

Hasil penelitian ini menunjukkan bahwa kecerdasan intelektual menjadi suatu kemampuan penting untuk melakukan berbagai aktivitas di tempat kerja. Moniaga (2013) menunjukkan kecerdasan intelektual berpengaruh signifikan terhadap kinerja karyawan. Rahmasari (2012) juga menunjukkan kecerdasan intelektual berpengaruh positif terhadap kinerja karyawan. Wijaya (2014) menagaskan peran kecerdasan intelektual terhadap peningkatan kinerja karyawan. Ole karena itu, penelitian ini mendukung penelitian yang menunjukkan pengaruh siginifikan positif kecerdasan intelektual terhadap kinerja karyawan. Walaupun demikian, penelitian ini tidak mendukung hasil penelitian Al Fharied (2014) yang menunjukkan kecerdasan intelektual tidak berpengaruh terhadap kinerja karyawan.

Kecerdasan emosional berpegaruh positif terhadap kinerja karyawan. Peningkatan kecerdasan emosional akan meningkatkan kinerjanya. Hasil analisis menunjukkan besarnya pengaruh kecerdasan emosional sebesar 0,196 terhadap kinerja karyawan. Sedangkan, probabilitas t hitung sebesar 0,016. Oleh karena itu, kecerdasan emosional berpengaruh signifikan positif terhadap kinerja karyawan.

Keunggulan kompetitif dibentuk melalui berbagai cara, salah satunya melalui peningkatan kecerdasan emosional. Mangkunegara (2005) menyatakan keungulan bersaing dapat dicapai dengan cara meningkatkan pengelolaan manajemen sumber daya manusia secara efektif melalui peningkatan kecerdasan emosional.

Kecerdasan emosional sangat penting untuk mencapai keberhasilan. Goleman (2000) menyatakan kecerdasan lain yang mempengaruhi keberhasilan seseorang yaitu kecerdasan emosi. Sutrisno (2010) juga menyatakan bahwa kecerdasan emosional mampu menciptakan kepercayaan dan menjadi salah satu faktor keberhasilan seseorang.

Penelitian ini sejalan dengan hasil penelitian yang dilakukan oleh penelitian sebelumnya, yakni; Rahmasari (2012); Wijaya (2014). Mereka 
menunjukkan kecerdasan emosional memiliki pengaruh positif signifikan terhadap kinerja karyawan.

Karyawan Puskesmas senantiasa berhadapan dengan orang berbeda setiap hari. Mereka dituntuk memberikan pelayanam yang prima. Mekanisme pekerjaan membutuhkan kerjasama yang baik antar anggota. Sistem kerja ini tidak dapat dipisahkan dari satu bagian dengan bagian yang lain. Oleh karena itu, kesadaran diri dan kesedaran berhubungan dengan orang lain memiliki peran penting dalam unit pelayanan kesehatan.

Unit pelaksana teknis setingkat Puskesma di Kabupaten Madiun melakukan program-program yang bertujuan meningkatkan kecerdasan emosional. Hal ini terkait dengan peningkatan semangat kerja karyawan dan motivasi kerja. Program kegiatan tersebut diantaranya melalui olah raga bersama seluruh karyawan, rekreasi, serta pelatihan ESQ dan seminar motivasi yang diikuti oleh karyawan yang ditunjuk pada waktu-waktu tertentu.

Variabel kecerdasan spiritual memiliki pengaruh signifikan positif terhadap kinerja karyawan. Hasil analisis menunjukkan nilai t hitung sebesar 5,677. Sedangkan probabilitasnya sebesar 0,000. Besarnya koefisien beta adalah 0,424 dengan nilai positif. Hal ini dapat dijelaskan bahwa peningkatan kecerdasan spiritual dapat meningkatkan kinerja karyawan.

Hasil penelitian ini konsisten dengan penelitian yang dilakukan oleh Wijaya (2014); Rahmasari (2012); dan Moniaga (2013). Mereka menunjukkan bahwa kecerdasan spiritual berpengaruh signifikan positif terhadap kinerja karyawan. Kecerdasan spiritual merupakan wujud kesadaran pada nilai-nilai yang luhur. Sutrisno (2010) menyatakan bahwa kecerdasan spiritual membentuk manusia agar memiliki tanggung jawab dan memiliki kesadaran akan nilai-nilai luhur. Sedangkan, Agustian (2001) berpendapat bahwa kecerdasan emosional akan mampu memberi makna spiritual terhadap pemikiran, perilaku dan kegiatan seorang individu.

Kecerdasan spiritual memiliki pengaruh dominan terhadap kinerja karyawan. Kontribusi variabel kecerdasan spiritual terhadap kinerja karyawan paling tinggi dibandingkan dua variabel yang lain. Hal tersebut dapat dilihat dari nilai koefisien beta $(\beta)$ pada tabel 4 . Hasil penelitian ini menunjukkan kecerdasan spiritual merupakan landasan untuk membangun kecerdasan intelektual dan kecerdasan emosional yang efektif. Zohar dan Marshall (2002:4) menyatakan kecerdasan spiritual sebagai kecerdasan tertinggi manusia.

Beberapa program peningkatan kecerdasan spiritual yang diselenggarkan di obyek penelitian ini, yakni; (1) memberikan kesempatan 
Fitri Setya Ma'rufah, Siswanto

untuk menjalankan ibadah sesuai dengan keyakinannya,

menyelenggarakan kegiatan keagamaan (3) menyelenggaran kegiatan pengajian bagi setiap karyawan muslim, (4) mengadakan pelatihan ESQ.

\section{Kesimpulan}

Berdasarkan hasil analisis data dan pembahasan, maka dapat disimpulkan bahwa variabel kecerdasan intelektual berpengaruh positif signifikan terhadap kinerja karyawan. Kecerdasan emosional berpengaruh positif signifikan terhadap kinerja karyawan. Kecerdasan spiritual berpengaruh positif signifikan terhadap kinerja karyawan. Kecerdasan spiritual memiliki pengaruh yang dominan terhadap kinerja karyawan.

Penelitian ini memberikan rekomendasi agar meningkatkan kecerdasan spiritual. Karena, kecerdasn ini memiliki implikasi yang paling penting dalam peningkatan kinerja karyawan. Sedangkan, untuk penelitian selanjutnya dapat memasukkan variabel lain yang dapat memprediksikan peningkatan kinerja karyawan.

\section{DAFTAR PUSTAKA}

Agustian, A. G. 2001. Rahasia Sukses Membangun Kecerdasan Emosi dan Spiritual (ESQ). Jakarta: Arga Wijaya Persada.

Al Fharied. Z. W. 2014. Pengaruh Kecerdasan Emosional (EQ), Kecerdasan Intelektual (IQ), dan Kecerdasan Spiritual (SQ) terhadap Kinerja Karyawan pada LPP TVRI Riau, Pekanbaru, Skripsi, Fakultas Ekonomi dan Ilmu Sosial Universitas Islam Negeri Sultan Syarif Kasim, Riau.

Ardana, I Komang,, Mujiati, Ni Wayan,, Utama, I Wayan Mudiarti. 2012. Manajemen Sumber Daya Manusia. Yogyakarta: Graha Ilmu.

Artana, Made Buda, Herawati, Nyoman Trisna, Atmadja, Ananta Wikrama Tungga. 2014. Pengaruh Kecerdasan Intelektual (IQ), Kecerdasan Emosional (EQ), Kecerdasan Spiritual (SQ), dan Perilaku Belajar terhadap Pemahaman Akuntansi (Studi Kasus pada Mahasiswa S1 Akuntansi Universitas Pendidikan Ganesha dan Mahasiswa S1 Universitas Udaayana Denpasar), Jurnal, 2 (1), Akuntansi Universitas Pendidikan Ganesha, Singaraja, Diperoleh tanggal 29 September 2015 pukul 8:19 WIB dari ejournal,undiksha,ac,id/.../3395.

Azwar, Saifuddin. 2006. Pengantar Psikologi Intelegensi. Yogyakarta: Pustaka Pelajar.

Dwijayanti, Arie Pangestu. 2009. Pengaruh Kecerdasan Emosional, Kecerdasan Intelektual, Kecerdasan Spiritual, dan Kecerdasan Sosial terhadap Pemahaman Akuntansi. Skripi. Fakultas Ekonomi Universitas Pembangunan Nasional "Veteran", Jakarta, Diperoleh pada 29 Desember 2015 pada 09:00 WIB dari repository,usu,ac,id/bitstream/.

Efendi, Agus. 2005. Revolusi Kecerdasan Abad 21: Kritik NI, EI, SQ, AQ, \& Successful Intelligence Atas IQ, Bandung: Alfabeta.

54 | IQTISHODUNA Vol. 15 No. 1 Tahun 2019

http://ejournal.uin-malang.ac.id/index.php/ekonomi 
Ghozali, Imam. 2011. Aplikasi Analisis Multivariat dengan Program IBM SPSS 19, Semarang: Badan Penerbitan UNDIP.

Goleman, Daniel. 1999. Kecerdasan Emosi: untuk Mencapai Puncak Prestasi, Terjemah oleh Alex Tri Kantjono. 1999. Jakarta: Gramedia Pustaka Utama.

Goleman, Daniel. 2000. Kecerdasan Emosi: Mengapa Emotional Intelligence Lebih Tinggi daripada IQ. Terjemah oleh T, Hermay. 2000. Jakarta: Gramedia Jakarta Utama.

Mangkunegara, Anwar Prabu. 2005. Evaluasi inerja SDM. Bandung: Refika Aditama.

Mangkunegara, Anwar Prabu. 2005. Manajemen Sumber Daya Manusia Perusahaan. Bandung: Remaja Rosdakarya.

Mathis, Robert L,, Jackson, John H. 2002. Manajemen Sumber Daya Manusia, Jakarta: Salemba Empat.

Moniaga, Pingkan. 2013. Analisis Pengaruh Kecerdasan Emosional, Kecerdasan Spiritual, dan Kecerdasan Intelektual terhadap Kinerja Karyawan (Studi Kasus pada PT, Bank Sulut Kantor Pusat). Jurnal, Fakultas Ekonomi dan Bisnis Program Pasca Sarjana Magister Manajemen Universitas Sam Ratulangi, Manado, Diperoleh tanggal 26 November 2015 pukul 10:18 WIB dari http://ejournal,unsrat,ac,id/index,php/jrbm/article/view/2515.

Munir, Ningky. Juli 2000. Spiritualitas dan Kinerja. Majalah Manajemen. 124.

Nisfiannoor, Muhammad. 2009. Pendekatan Statistik Modern untuk Ilmu Sosial, Jakarta: Salemba Empat.

Pasiak, Taufiq. 2002. Revolusi IQ/EQ/SQ: antara Neurosains dan Al-Qur'an. Bandung: PT Mizan Pustaka.

Rahmasari, Lisda. 2012. Pengaruh Kecerdasan Intelektual, Kecerdasan Emosi dan Kecerdasan Spiritual terhadap Kinerja Karyawan. Jurnal, Fakultas Ekonomi Universitas AKI, Semarang, Diperoleh tanggal 29 September 2015 pukul 08:03 WIB dari www,unaki,ac,id/ejournal/in-dex,php/jurnalinfor-matika/article/view/3.

Rivai, Veithzal. 2006. Manajemen Sumber Daya Manusia untuk Perusahaan: dari Teori ke Praktik. Jakarta: PT, RajaGrafindo Persada.

Robbins, S,P,, Judge, T,A. 2008. Organizational Behavior (ed,13). US: Prentice Hall.

Simanjorang, Debora, Sipayung, Friska. 2012. Pengaruh Kecerdasan Intelektual, Kecerdasan Emosional dan Kecerdasan Spiritual terhadap Sikap Etis Mahasiswa Manejemen Fakultas Ekonomi Universitas Sumatera Utara. Jurnal. 15 (2), Fakultas Ekonomi Universitas Sumatera Barat, Diperoleh tanggal 02 Maret 2016 pukul 08:25 WIB dari repository,usu,av,id/bitstream/1234.

Siswanto. 2012. Creating the superior Islamic Banking through Improving Quality of Human Resources, Jakarta: Kementerian Agama RI

Sutrisno, Edy. 2010. Budaya Organisasi, Jakarta: Kencana.

Tika, Moh, Pabundu. 2006. Budaya Organisasi dan Peningkatan Kinerja Perusahaan. Jakarta: PT Bumi Aksara. 
Fitri Setya Ma'rufah, Siswanto

Trihandini, R,A Fabiola. 2005. Analisis Pengaruh Kecerdasan Intelektual, Kecerdasan Emosi dan Kecerdasan Spiritual terhadap Kinerja Karyawan (Studi Kasus di Hotel Horison Semarang). Tesis, Program Studi Magister Manajemen Program Studi Pascasarjana Universitas Dionegoro, Semarang, Diperoleh tanggal 29 September 2015 pukul 08:00 WIB dari http://eprints,undip,ac,id/15539/.

Wahab, A, Umiarso. 2011. Kepemimpinan Pendidikan dan Kecerdasan Spiritual. Yogkarta: Ar-Ruzz Media.

Waryanti, Sesilia Dwi Rini. 2011. Analisis Pengaruh Kecerdasan Emosional dan Kecerdasan Spiritual terhadap Kinerja Karyawan (Studi Empiris pada Rumah Sakit Umum Daerah Kota Semarang). Skripsi. Fakultas Ekonomika dan Bisnis Universitas Diponegoro, Semarang, Diperoleh tanggal 29 September 2015 pukul 08:10 WIB dari repository,unej,ac,id/bitstream.

Wiersma, M,L. 2002. The Influence of Spiritual Meaning-Making on Career Behaviour. Journal of Management Development. 21. 497-520, Diperoleh tanggal 29 Desember 2015 pukul 06:42 WIB dari http://www,holisticdevelopment,org,nz/Media/Default,PageWithRightSi deContent/resources/academicarticles/influence_spiritual,pdf\&hl=id\&sa $=\mathrm{X} \&$ scisig=AAGBfm14aiybwyrifobgbQDLaww09CSKGZw\&nossl=1\&oi=sc holarr.

Wijaya, Claudia Angelika. 2014. Analisa Pengaruh Kecerdasan Intelektual, Kecerdasan Emosional, dan Kecerdasan Spiritual terhadap Kinerja Karyawan di Hotel "X". Jurnal. Manajemen Perhotelan Universitas Kristen Petra Surabaya Indonesia, Surabaya, Diperoleh tanggal 28 September 2015 pukul 07:45 WIB dari studentjournal,petra,ac,i.,

Zohar, Danah,, Marshall, Ian. 2002. Memanfaatkan Kecerdasan Spiritual dalam Berpikir Intergralistik dan Holistik untuk Memaknai Kehidupan. Bandung: Mizan.

Zohar, Danah,, Marshall, Ian. 2005. Spiritual Capital: Memberdayakan SQ di Dunia Bisnis. Bandung: Mizan. 